\title{
Phytoconstituent Analysis and Antibacterial Potential of Epicarp Extracts from Mature Fruits of Persea americana Mill
}

\author{
Cyuzuzo Callixte1, Dusabimana Jean Damascene ${ }^{1,2}$, Anwar Ma'ruf, ${ }^{3}$, Yoes Prijatna Dachlan, \\ Anggraini Dwi Sensusiati ${ }^{5}$, Ndayisaba Daniel ${ }^{2}$, Eka Nora Vitaloka Aprilia Putri Winthoko ${ }^{1}$ \\ ${ }^{1}$ Graduate Program in Immunology, School of Postgraduate, Universitas Airlangga, Surabaya, Indonesia \\ ${ }^{2}$ Biology Department, College of Science and Technology, University of Rwanda, Kigali, Rwanda \\ ${ }^{3}$ Faculty of Veterinary, Universitas Airlangga, Surabaya, Indonesia \\ ${ }^{4}$ Departement of Parasitology, Faculty of Medicine, Universitas Airlangga, Surabaya, Indonesia \\ ${ }^{5}$ Department of Radiology, Faculty of Medicine, Airlangga University, Surabaya, Indonesia
}

Background: World Health Organization (WHO) has reported the antimicrobial resistance as one among the ten threats to global health in 2019. The development of plant-derived antibiotics is currently considered as a modern medicine's greatest success. Persea americana is a plant with high medicinal profile which allow its different parts to be used for therapeutic purposes. This study is aimed to determine the antibacterial potential of ethanol and chloroform extracts from epicarp of mature fruits of $P$. americana Mill against human pathogens.

Materials and Methods: The epicarps of avocado were dried in oven and ground into powder using porcelain mortar and pestle. The powdered plant materials were extracted with both $96 \%$ ethanol and chloroform. Extracts were qualitatively screened to examine their bioactive contents and agar well diffusion method was used to analyze the antibacterial activity of extracts against both Gram-positive and Gram-negative bacteria.

Results: Both solvents showed the ability to dissolve the secondary metabolites from avocado epicarps. Phytochemical screening disclosed the presence of alkaloids, proteins, terpenoids, tannins, flavonoids, steroids and phenolic compounds in ethanolic extracts and absence of flavonoids and tannins in chloroform extracts. The extracts showed the inhibition zones ranging from $14 \pm 4.5 \mathrm{~mm}$ to $26 \pm 2.1 \mathrm{~mm}$ while streptomycin demonstrated high inhibition zones ranging from $20 \pm 3.1 \mathrm{~mm}$ to $30 \mathrm{~mm}$. The minimum inhibitory concentration (MIC) values of extracts ranges from $0.3125 \mathrm{mg} / \mathrm{mL}$ to $20 \mathrm{mg} / \mathrm{mL}$ while the MIC values for streptomycin vary from $0.25 \mathrm{mg} / \mathrm{mL}$ to $1.25 \mathrm{mg} / \mathrm{mL}$.

Conclusion: The ethanol and chloroform extracts proved to be potentially effective as natural alternative preventives to fight against various disease-causing bacteria.

Keywords: antibacterial activity, ethanol extract, chloroform extract, Persea americana, Rwanda

Date of submission: September 9, 2019

Last Revised: October 25, 2019

Accepted for publication: November 12, 2019

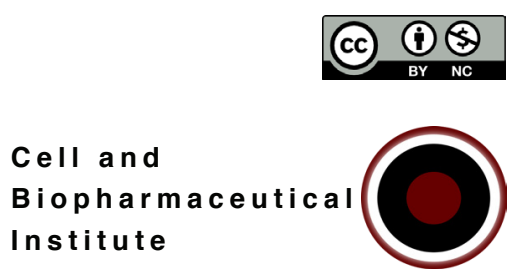

Corresponding Author:

Cyuzuzo Callixte

Department of Immunology, School of Postgraduate

Universitas Airlangga, Kampus C

Jl. Unair, Mulyorejo, Gubeng, Surabaya, Indonesia

e-mail: cyuzuzocallixte@gmail.com 


\section{Introduction}

Avocado (Persea americana Mill) is a medicinal plant which belongs to the genus Persea of the family Lauraceae. It is believed to have originated from Central America and it is now cultivated in tropical regions worldwide. ${ }^{1}$ Avocado contains oxygenated carotenoids and the major bioactive compounds that shield human cells from the effects of free radicals. It also consists of persenone $\mathrm{A}$ and $\mathrm{B}$ which hamper the generation of both superoxide and nitric oxide in cell culture, and fight against inflammation and carcinogenesis. ${ }^{2}$ Avocado fruit consists of persin which reduces the larval growth of Spodoptera exigua and serve as an antifungal agent against Colletotrichum gloeosporioides. ${ }^{3}$

Epicarp extracts of avocado is commonly known to have bioactive substances like peptone, alkaloids, steroids, triterpenoids, tannins, flavonoids, saponins, and polyphenols which should have antimicrobial potential against different pathogens. ${ }^{4,5}$ They also consist of $\beta$-galactoside, glycosylated abscisic acid, cellulose, polygalactourease, polyuronoids, cytochrome P-450, and triacylglycerol which work singlehandedly or collectively to treat monorrhagia, high blood pressure, stomach discomfort, bronchitis, diarrhea and other polygenic disorders including diabetes. ${ }^{1}$

The unripe avocado fruits contain 1,2,4-trihydroxyheptadec-16-yne which has ability to repress mosquito-borne virus activity without cytotoxicity but by inducing NF-kB-mediated antiviral interferon responses. ${ }^{6}$ They also have 1,2,4-trihydroxyheptadec-16ene and 1,2,4-trihydroxynonadecane which are known to have moderate cytotoxic activities against cancer cells. ${ }^{7,8}$

Avocado fruits consist of catechins, epicatechins, procyanidins and hydroxycinnamic acid with liver repressing activity by modifying the plasma levels of glutamate-pyruvate transaminase, albumin, glutamic oxaloacetic transaminase and creatinine. ${ }^{9,10}$ Avocado fruits contain vitamins ( $\mathrm{E}$ and $\mathrm{B}$ ), potassium and other saturated fatty acids ${ }^{11}$, which have been documented to possess a lot of biologically active properties such as antibacterial ${ }^{12}$, antiviral $^{13}$, antioxidant ${ }^{14}$, anti-atherosclerotic ${ }^{15}$ and hepatoprotective ${ }^{16}$.

Avocado extracts possess quercetin which has virustatic ability to inhibit human immunodeficiency virus syncytium and viral p24 antigen formations. ${ }^{17}$ They also contain afzelin and quercetin 3-O-D-arabinopyranoside which have repulsive potential against herpes s implex virus type 1 , Aujeszky's disease virus and adenovirus type-
3 by inhibiting acyclovir-resistant herpes simplex virus type $1 .^{3}$

The current research is intended to light its beams on the phytoconstituents screening and antibacterial activity of crude ethanol and chloroform epicarp extracts of mature fruits of P. americana L grown in Rwanda.

\section{Materials and methods}

\section{Plant Sample Preparation}

Mature ripen $P$. americana Mill fruits were rigorously collected in Busogo sector, Musanze district, Northern province, Rwanda. Avocado fruits were chosen depending on their solidity, absence of mechanical injury and observable rot. The collected fruits were carefully washed with sterile water and cut open to distinguish the edible parts and epicarps. The epicarps were dried in an oven at $60^{\circ} \mathrm{C}$ and eventually blended into powder with the help of a porcelain mortar and pestle.

\section{Plant Material Extraction}

The extraction experiment was aseptically performed in Biotechnology laboratory at room temperature. $P$. americana Mill powder was successfully macerated with $96 \%$ ethanol (1:5) and chloroform for 3 days using rotary shaker. After extraction, the extracts were decanted and then filtered through Whatman filter paper No. 1. Crude extracts were obtained by evaporating the solvents using rotary evaporator. The yielded thick extracts were dissolved in $2 \%$ Sodium Carboxymethyl Cellulose (CMC Na $2 \%$ ) and kept in labelled containers at $4^{\circ} \mathrm{C}$ until their use.

\section{Phytochemical Screening}

Systematic phytochemical screening was carried out to assess the presence of bioactive components in crude epicarp extracts according to standard method. ${ }^{18}$ The qualitative analysis tests were performed for various phytoconstituents such as flavonoids (Shinoda test), steroids (Salkowski test), tannins (Ferric chloride test), alkaloids (Wagner test), saponins (Froth test), proteins (Xanthoproteic test) and phenolic compounds were examined by diluting the extract with distilled water up to $5 \mathrm{~mL}$ and added 3 drops of $5 \%$ ferric chloride solution. The availability of phenols in the extracts was confirmed by the change in colors to dark green. Terpenoids were tested by mixing $5 \mathrm{~mL}$ of the crude extracts with $3 \mathrm{~mL}$ of chloroform and eventually added $2 \mathrm{~mL}$ of concentrated sulphuric acid. The presence 
of terpenoids was absolutely revealed by the formation of brown ring.

\section{Test Bacteria}

In this study, the used bacteria were all human pathogens isolated from clinical specimens. Pure cultures of Pseudomonas aeruginosa ATCC 27853, Staphylococcus pyogenes ATCC 21059, Bacillus subtilis ATCC 6633 and Klebsiella pneumoniae ATCC 4352 used to assess the antibacterial properties were obtained from Bacteriology Department in clinical laboratory of University Teaching Hospital of Butare. The bacteria were collected on sterile plates and incubated at $37^{\circ} \mathrm{C}$ for 24 hours. A single colony of each test bacteria was diluted in $9 \mathrm{~mL}$ of peptone water and acclimatized to give the equal concentration of bacterial cells of $10^{6}$ colony forming unit $/ \mathrm{mL} .{ }^{19}$

\section{Antibacterial Assay of The Extracts}

According to National Committee for Clinical Laboratory Standards, the antibacterial activity of the extracts was determined by agar well diffusion method. ${ }^{20,21}$ Twenty five $\mu \mathrm{L}$ of diluted bacteria were swabbed on agar plates using cotton swabs and Pasteur pipette was used to create wells of $8 \mathrm{~mm}$. Twenty milligrams of each extract $(30 \mathrm{mg} / \mathrm{mL})$ was impregnated in created wells and $20 \mathrm{mg}$ of Streptomycin (30 $\mathrm{mg} / \mathrm{mL}$ ) was used as control. The plates were then incubated in upright position at $37^{\circ} \mathrm{C}$ for 24 hours. All tests were done in triplicate and the antibacterial potential was recorded as the mean \pm standard deviation by estimating the inhibition zones with Vernier caliper. The activity index for each extract was calculated by dividing the inhibition zone of the sample with the inhibition zone of the standard antibiotic.

\section{The Determination of Minimum Inhibitory Concentration (MIC)}

MIC was determined by broth dilution method. ${ }^{22}$ The extracts were serially diluted from $40 \mathrm{mg} / \mathrm{mL}$ to 0.3125 $\mathrm{mg} / \mathrm{mL}$ and filled in different created wells. Ten $\mu \mathrm{L}$ of each bacterial culture at a density of $10^{6} \mathrm{CFU} \mathrm{mL}-1$ were inoculated on the broth. Control of bacterial growth was also performed and Streptomycin was used as a positive control. All plates were incubated at $37^{\circ} \mathrm{C}$ for 24 hours. MICs were noted as the smallest concentration of extracts that showed no observable growth of microorganisms after nightlong incubation.

\section{Results}

\section{Phytochemical Analysis}

Phytochemical screening clearly confirmed the presence of alkaloids, proteins, terpenoids, tannins, flavonoids, steroids and phenolic compounds in ethanolic extracts and absence of flavonoids and tannins in chloroform extracts. The availability and absence of these secondary metabolites were clearly shown by the results presented in Table 1 .

\section{Antibacterial Activity}

The findings of antimicrobial assay revealed that streptomycin had more potential compared to ethanolic and chloroform extracts. Both extracts were able to inhibit Gram positive bacteria (S. pyogenes and B. subtilis) stronger than Gram negative bacteria ( $P$. aeruginosa and $K$. pneumoniae) (Table 2). This potential was also confirmed by their activity indexes (Table 3 ) and their respective MICs (Table 4).

The activity indexes of the evaluated extracts in relation to antibiotic demonstrated that $S$. pyogenes was more sensitive than other tested bacteria. For both chloroform and ethanolic extracts, this Gram-positive bacterium showed great sensitivity than B. subtilis and other tested Gramnegative bacteria.

The MIC was the lowest concentration that demonstrated the ability to inhibit the visible growth of bacteria after an overnight incubation. From the current findings, streptomycin as a refined antibiotic exhibited high activity compared to both extracts. When the concentration was smaller and its inhibitory activity was high, this confirm

Table1. The results of the chemical tests of the crude epicarp extracts of $P$. americana fruits.

\begin{tabular}{lcccccccc}
\hline Extracts & Flavonoids & Steroids & Terpenoids & Saponins & Tannins & Proteins & Alkaloids & Phenols \\
\hline Ethanolic & + & + & + & + & + & + & + \\
Chloroform & - & + & + & + & + & + & + \\
\hline
\end{tabular}


Table 2. Antimicrobial activity of each epicarp extracts.

\begin{tabular}{lccc}
\hline & \multicolumn{3}{c}{ Inhibition Zones (mm) } \\
\cline { 2 - 4 } \multicolumn{1}{c}{ Bacteria } & $\begin{array}{c}\text { Ethanolic Extract } \\
\mathbf{( 2 0} \mathbf{~ m g})\end{array}$ & $\begin{array}{c}\text { Chloroform Extract } \\
(\mathbf{2 0} \mathbf{~ m g})\end{array}$ & $\begin{array}{c}\text { Streptomycin } \\
\mathbf{( 3 0} \mathbf{~ m g / m L )}\end{array}$ \\
\hline P. aeruginosa ATCC 27853 & $17 \pm 3.3$ & $15 \pm 0.9$ & 25 \\
S. pyogenes ATCC 21059 & $20 \pm 0.7$ & $19 \pm 0.4$ & 22 \\
B. subtilis ATCC 6633 & $26 \pm 2.1$ & $18 \pm 1.6$ & 30 \\
K. pneumoniae ATCC 4352 & $17 \pm 0.2$ & $14 \pm 4.5$ & 20 \\
\hline
\end{tabular}

the high antibacterial activity of tested plant extract. Even if ethanol and chloroform were all organic solvents, ethanol had demonstrated high inhibitory activity than chloroform as it can be observed in Table 4.

\section{Discussion}

This research was conducted to evaluate the phytoconstituents and antipathogenic capabilities of epicarp extracts from fruits of $P$. americana Mill. The main findings of this research revealed that epicarp of avocado contain secondary metabolites with antibacterial properties.

The findings presented in Table 1 disclosed the existence of tannins, steroids, saponins and flavonoids in ethanolic extract which have antibacterial activities. These results are in agreement with the findings reported by other researchers that one or combination of these active substances has/have ability to inhibit microbial cell wall synthesis by creating irremediable compounds with abundant prolene growth factor. ${ }^{23}$ The observed plant derived antimicrobials control bacterial growth by modifying their membrane porosity or decreasing their $\mathrm{pH} .{ }^{24}$ These membrane agitations together

Table 3. The activity indexes of each epicarp extracts in accordance to the standard antibiotic.

\begin{tabular}{lcc}
\hline \multirow{2}{*}{ Bacteria } & \multicolumn{2}{c}{ Activity Indexes } \\
\cline { 2 - 3 } & $\begin{array}{c}\text { Ethanolic } \\
\text { Extracts }\end{array}$ & $\begin{array}{c}\text { Chloroform } \\
\text { Extracts }\end{array}$ \\
\hline P. aeruginosa ATCC 27853 & 0.68 & 0.6 \\
\hline S. pyogenes ATCC 21059 & 0.9 & 0.86 \\
\hline B. subtilis ATCC 6633 & 0.86 & 0.6 \\
\hline K. pneumoniae ATCC 4352 & 0.85 & 0.7 \\
\hline
\end{tabular}

Note: Activity indexes=Inhibition zone of extracts/ Inhibition zone of standard antibiotic. with the activity of $\beta$-lactams on the transpeptidation of the plasma membrane and eventually accelerate the inhibitory activity of the extracts. ${ }^{25}$ The extracts clearly showed the ability to cause leakage of proteins and some enzymes from the cell. These substances have abilities to disrupt binary fission, to interact with extracellular proteins and to damage the integrity of bacterial cell walls..$^{26,27}$ The variability in antipathogenic capabilities of the extracts also depends on the quantity of active substances present in extracted plant parts. Epicarp, roots, leaves, fruits, stems and seeds have different allotment of chemical compounds. ${ }^{28}$ The accumulation of the bioactive substances in plant also depends on the stage of maturity, rainfall, seasonality, soil salinity and other agroecological conditions ${ }^{29}$, which impede or enhance water absorption, physiological and chemical processes during plant metabolism ${ }^{30}$.

Both ethanolic and chloroform extracts demonstrated great antibacterial activity against tested bacteria. This result absolutely revealed the effectiveness of organic solvents to dissolve bioactive compounds from plants due to their polarity which influenced their biological activities. ${ }^{31}$ This finding is as well in tandem with the result of other study which reported that solvent solubility has a vital role to extract the plant natural products from different plant parts. ${ }^{32}$

The plant extracts inhibit microbial growth by associating with non-polar compounds in the hydrophobic interior of the membrane and by the formation of hydrogen bonds between the polar head groups of lipids and the more hydrophilic flavonoids at the membrane interface. The antimicrobial activity of flavonoids is explained by the fact that they reduce fluidity in hydrophilic and hydrophobic regions of both inner and outer plasma membrane and cause biofilm perturbation. ${ }^{33}$ The high antimicrobial activity of flavonoids is owed to 3-O-octanoyl-epicatechin which enhance membrane affinity of their long acyl chains. The 
Table 4. The MIC of the extracts against the tested pathogens.

\begin{tabular}{lccc}
\hline \multicolumn{1}{c}{ Bacteria } & \multicolumn{3}{c}{ MIC $(\mathbf{m g} / \mathbf{m L})$} \\
\cline { 2 - 4 } & $\begin{array}{c}\text { Ethanolic Extract } \\
(\mathbf{2 0 ~} \mathbf{~ m g})\end{array}$ & $\begin{array}{c}\text { Chloroform Extract } \\
(\mathbf{2 0} \mathbf{~ m g})\end{array}$ & $\begin{array}{c}\text { Streptomycin } \\
\mathbf{( 3 0} \mathbf{~ m g / m L})\end{array}$ \\
\hline P. aeruginosa ATCC 27853 & 5 & 10 & 0.75 \\
S. pyogenes ATCC 21059 & 0.3125 & 1.25 & 0.25 \\
B. subtilis ATCC 6633 & 0.625 & 2.5 & 0.5 \\
K. pneumoniae ATCC 4352 & 10 & 20 & 1.25 \\
\hline
\end{tabular}

flavonoids lacking hydroxyl groups on their B rings are the most effective to hinder microbial membranes than those with hydroxyl $(\mathrm{OH})$ groups. ${ }^{34}$

The findings of the current evaluation showed that Gram-positive bacteria were more sensitive to all extracts than Gram-negative bacteria. ${ }^{35}$ This statement could be explained by the fact that Gram-positive and Gram-negative bacteria have different cell wall composition. Gramnegative outer membrane consists of phospholipids and lipopolysaccharides that act as a fence to the entrance and reaction of most antibiotics and antimicrobial compounds through cell envelope. ${ }^{22,36} S$. pyogenes ATCC 21059 as a Gram-positive bacterium showed high sensitivity to the extracts with the activity index of 0.90 as clearly indicated by the findings presented in Table 3. This finding is absolutely correlated with previous result which reported the pronounced sensitivity of Staphylococcus species due to their cell walls and outer membranes. ${ }^{37}$

In the present investigation, antibiotic exhibited high inhibitory activity than the prepared plant extracts as shown in Table 2. The observed effectiveness of antibiotic than the plant extracts may be due to the fact that the antibiotics are in refined states and naturally purified while plant extracts are still in crude states. ${ }^{38}$

\section{Conclusion}

All in all, the present findings provide scientific justification that the epicarp extracts of $P$. americana Mill have potential bioactive substances such as flavonoids and phenolic compounds. From that perspective, avocado extracts contain antimicrobial agents that could be contemplated to develop the effectual treatment modalities for fighting pathogens that are resistant to typical antibiotics. They as well give a great hope that avocado epicarp extracts can be used by pharmaceutical industries to produce valuable medicines to mitigate microbial infections.

\section{References}

1. Mohammad Y, Sattwik D, Kharya MD. The phytochemical and pharmacological profile of Persea americana Mill. Pharmacogn Rev. 2010; 4(7): 77-84.

2. Domergue F, Helms GL, Prusky D, Browse J. Antifungal compounds from idioblast cells isolated from avocado fruits. Phytochemistry. 2000; 54(2): 183-9.

3. Rodriguez-Saona C, Millar JG, Trumble JT. Isolation, identification, and biological activity of isopersin: a new compound from avocado idioblast oil cells. J Nat Prod. 1998; 61: 1168-70.

4. Torres RC, Garbo AG, Walde RZM. Lavicidal activity of Persea americana Mill. against Aedes aegypti. Asian Pac J Trop Med. 2014; 7 (Suppl 1): S167-70.

5. Kosińska A, Karamać M, Estrella I, Hernández T, Bartolomé B, Dykes GA. Phenolic compound profiles and antioxidant capacity of Persea americana Mill. peels and seeds of two varieties. J Agric Food Chem. 2012; 60(18): 4613-9.

6. Wu YH, Tseng CK, Wu HC, Wei CK, Lin CK, Chen IS, et al. Avocado (Persea americana) fruit extract (2R,4R)-1,2,4-trihydroxyheptadec16-yne inhibits dengue virus replication via upregulation of NF$\mathrm{\kappa B}$-dependent induction of antiviral interferon responses. Sci Rep. 2019; 9(1): 423. doi: 10.1038/s41598-018-36714-4.

7. Ambasta SP. The Useful Plants of India. New Delhi: CSIR; 1986.

8. Oberlies NH, Rogers LL, Martin JM, McLaughlin JL. Cytotoxic and insecticidal constituents of the unripe fruit of Persea americana. J Nat Prod. 1998; 61(6): 781-5.

9. Kawagishi H, Fukumoto Y, Hatakeyama M, He P, Arimoto H, Matsuzawa $\mathrm{T}$, et al. Liver injury suppressing compounds from avocado (Persea americana). J Agric Food Chem. 2001; 49(5): 2215-21.

10. Jiménez AA, León DR, Meckes M, Tapia A, Molina-Salinas GM, Luna HJ, et al. Antiprotozoal and antimycobacterial activities of pure compounds from Aristolochia elegans rizhomes. Evid Based Complement Alternat Med. 2012; 2012: 593403. doi: $10.1155 / 2012 / 593403$.

11. Naveh E, Werman MJ, Sabo E, Neeman I. Defatted avocado pulp reduces body weight and total hepatic fat but increases plasma cholesterol in male rats fed diets with cholesterol. J Nutr. 2002; 132(7): 2015-8.

12. Neeman I, Lifshitz A, Kashman Y. New antibacterial agent isolated from the avocado pear. J Appl Microbiol. 1970; 19(3): 470-3.

13. Miranda MM. In vitro activity of extracts of Persea americana leaves on acyclovir-resistant and phosphonoacetic resistant Herpes simplex virus. Phytomedicine: international journal of phytotherapy and phytopharmacology. 1997; 4(4): 347-52. 
14. Lu YC, Chang HS, Peng CF, Lin CH, Chen IS. Secondary metabolites from the unripe pulp of Persea americana and their antimycobacterial activities. Food Chem. 2012; 135(4): 2904-9.

15. Akinpelu DA, Aiyegoro OA, Akinpelu OF, Okoh AI. Stem bark extract and fraction of Persea americana (Mill.) exhibits bactericidal activities against strains of bacillus cereus associated with food poisoning. Molecules. 2014; 20(1): 416-29.

16. Brai BI, Adisa RA, Odetola AA. Hepatoprotective properties of aqueous leaf extract of Persea Americana, Mill (Lauraceae) 'avocado' against CCL4-induced damage in rats. Afr J Tradit Complement Altern Med. 2014; 11(2): 237-44.

17. Wigg MD, Al-Jabri AA, Costa SS, Race E, Bodo B, Oxford JS. In vitro virucidal and virustatic anti-HIV-1 effects of extracts from Persea americana Mill. (avocado) leaves. Antivir Chem Chemother. 1996; 7(4): 179-83.

18. Edeoga HO, Okwu DE, Mbaebie BO. Phytochemical constituents of some nigerian medicinal plants. Afr J Biotech. 2005; 4(7): 685-8.

19. Samie A, Obi CL, Bessong PO and Namrita L. Activity profiles of fourteen selected medicinal plants from Venda Communities in South Africa against fifteen clinical Bacterial species. Afr J Biotech. 2005; 4(12): 1443-51.

20. National Committee for Clinical Laboratory Standards (NCCLS). M02-A12 Performance Standards for Antimicrobial Disc Susceptibility Tests; Approved Standard. 12th Edition. Villanova: NCCLS; 2015.

21. Nostro A, Germanŏ MP, D’AngeloV, Marino A, Cannattelli MA. Extraction methods and bioautography for evaluation of medicinal plants for antimicrobial activity. Lett Appl Microbiol. 2000; 30(5): 379-84.

22. Lennette EH, Balows A, Hausler WJ, Shadomy HJ. Manual of Clinical Microbiology. 4th ed. Washington DC: American Society for Microbiology; 1985.

23. Mamtha B, Kavitha K, Srinivasan KK, Shivananda PG. An in vitro study of the effect of Centella asiatica [Indian pennywort] on enteric pathogens. Indian J Pharmacol. 2004; 36(1): 41-3.

24. Srivastava J, Chandra H, Nautiyal AR, Kalra SJ. Antimicrobial resistance (AMR) and 5 plant-derived antimicrobials (PDAms) as an alternative drug line to control infections. Biotech. 2014; 4(5): 451-60.
25. Aiyegoro OA, Afolayan AJ, Okoh AI. In vitro antibacterial activities of crude extracts of the leaves of Helichrysum longifolium in combination with selected antibiotics. Afr J Pharm Pharmacol. 2009; 3(6): 293-300.

26. Zablotowicz RM, Hoagland RE, Wagner SC. Effect of saponins on the growth and activity of rhizosphere bacteria. Adv Exp Med Biol. 1996; 405: 83-95.

27. Van EJD, Bailey MJ. The ecology of transfer of mobile genetic elements. FEMS Microbiol Ecol. 2002; 42(2): 187-97.

28. Ramakrishna A, Ravishankar GA. Influence of abiotic stress signals on secondary metabolites in plants. Plant Signal Behav. 2011; 6(11): 1720-31.

29. Mayrhofer S, Teuber M, Zimmer ISL, Fischbach RJ, Schnitzler RP. Diurnal and seasonal variation of isoprene biosynthesis-related genes in grey poplar leaves. Plant Physiol.2005; 139(1): 474-84.

30. Munns R. Comparative physiology of salt and water stress. Plant Cell Environ. 2002; 25(2): 239-50.

31. Akujobi C, Anyanwu BN, Onyeze C, Ibekwe VI. Antibacterial activities and preliminary phytochemical screening of four medicinal plants. J Appl Sci. 2004; 7(3): 4328-38.

32. Idris S, Ndukwe GI, Gimba CE. Preliminary phytochemical screening and antimicrobial activity of seed extracts of Persea americana (avocado pear). Bayero J Pure Appl Sci. 2009; 2(1): 173-6.

33. Sanver D, Murray BS, Sadeghpour A, Rappolt M, Nelson AL. Experimental modeling of flavonoid-biomembrane interactions. Langmuir. 2016; 32(49): 13234-43.

34. Ikigai H, Nakae T, Hara Y, Shimamura T. Bactericidal catechins damage the lipid bilayer. Biochim Biophys Acta. 1993; 1147(1): 132-6.

35. Baron EJ, Peterson LR, Finegold SM. Bailey \& Scott's Diagnostic Microbiology. 9th ed. St. Louis: C.V. Mosby; 1994.

36. Paz M, Gúllon P, Barroso MF, Carvalho AP, Domingues VF, Gomes $\mathrm{AM}$, et al. Brazilian fruit pulps as functional foods and additives: Evaluation of bioactive compounds. Food Chem. 2015; 172: 462-8.

37. Zaika LL. Spices and herbs: their antimicrobial activity and its determination. J Food Saf. 1988; 9(2): 97-118.

38. Doughari JH, Pukuma MS, De N. Antibacterial effects of Balanites aegyptiaca L. Drel. and Moringa oleifera Lam. on Salmonella typhi. Afr J Biotechnol. 2007; 6(19): 2212-5. 